\title{
Antibody Engineering for Optimized Immunotherapy in Alzheimer's Disease
}

\author{
Isabelle L. Sumner ${ }^{1}$, Ross A. Edwards ${ }^{1}$, Ayodeji A. Asuni ${ }^{2}$ and Jessica L. Teeling ${ }^{1 *}$ \\ ${ }^{1}$ Biological Sciences, University of Southampton, Southampton, United Kingdom, ${ }^{2}$ Biologics, H. Lundbeck A/S, \\ Copenhagen, Denmark
}

There are nearly 50 million people with Alzheimer's disease (AD) worldwide and currently no disease modifying treatment is available. $A D$ is characterized by deposits of Amyloid- $\beta(A \beta)$, neurofibrillary tangles, and neuroinflammation, and several drug discovery programmes studies have focussed on $A \beta$ as therapeutic target. Active immunization and passive immunization against $A \beta$ leads to the clearance of deposits in humans and transgenic mice expressing human $A \beta$ but have failed to improve memory loss. This review will discuss the possible explanations for the lack of efficacy of $A \beta$ immunotherapy, including the role of a pro-inflammatory response and subsequent vascular side effects,

OPEN ACCESS

Edited by:

Wendy Noble,

King's College London,

United Kingdom

Reviewed by:

Alvaro Barrera-Ocampo,

ICESI University, Colombia

Thomas A. Bayer,

Gesellschaft für Wissenschaftliche

Datenverarbeitung (MPG), Germany

*Correspondence:

Jessica L. Teeling

jt8@soton.ac.uk

Specialty section:

This article was submitted to

Neurodegeneration,

a section of the journal

Frontiers in Neuroscience

Received: 08 January 2018

Accepted: 03 April 2018

Published: 23 April 2018

Citation:

Sumner IL, Edwards RA, Asuni AA and Teeling $J L$ (2018) Antibody

Engineering for Optimized

Immunotherapy in Alzheimer's

Disease. Front. Neurosci. 12:254.

doi: 10.3389/fnins.2018.00254 the binding site of therapeutic antibodies and the timing of the treatment. We further discuss how antibodies can be engineered for improved efficacy.

Keywords: amyloid, antibody engineering, immunotherapy, Alzheimers disease, neuroinflammation

\section{INTRODUCTION}

Alzheimer's Disease (AD) is the most common cause of dementia worldwide, characterized by variable mood changes, difficulty carrying out daily tasks, confusion, and progressive memory loss. An estimated 0.5 million people in the UK have Alzheimer's disease currently, and majority of these subjects 5 are age 65 or older. Which would suggest that as this population ages, the incidence of dementia will increase significantly. In fact, the incidence of AD worldwide is projected to triple by 2050 (https://www.alzheimers.org.uk/info/20007/types_of_dementia/2/ alzheimers_disease). Additional risk factors for AD which are beyond the scope of this review, include diabetes, high blood pressure, obesity, smoking, depression, as well as physical, and cognitive inactivity. Crucially, most of these are modifiable which gives hope to effort to reduce the incidences of $\mathrm{AD}$.

The current standard of care, such as donepezil (Aricept ${ }^{\circledR}$ ), galantamine (Reminyl ${ }^{\circledR}$ or Razadyne ${ }^{\circledR}$ ), and rivastigmine (Exelon ${ }^{\circledR}$ ) only alleviate the symptoms by increasing synaptic function and presently there are no approved therapies that can halt the progression of this dilapidating disease. AD is estimated to affect millions of people worldwide (Cynis et al., 2016) and numbers are predicted to increase as our population ages; therefore it is vital to find treatments to stop this disease, or delay the time hospitalization and institutionalization of the patients. The success rate of approving novel drugs is very low; with only $9.6 \%$ of candidates that enter clinical trials gaining FDA approval (www.bio.org; Cummings et al., 2017); the outlook for Alzheimer's drugs is even bleaker, with an approval rate of only $0.4 \%$ between 2002 and 2012; one of the poorest success rates of any disease (Cummings et al., 2014). There is good evidence that some lifestyle changes could alter the incidence of disease. One such change could be improvement of sleep 
quality. There is increasing evidence that poor sleep leads to higher levels of $A \beta$ in the brain, and in turn aberrant $A \beta$ levels further interferes with sleep and by extension memory consolidation (Diekelmann et al., 2009; Carvalho et al., 2018). This would suggest that targeting sleep represents a future avenue for treating AD. However, discussion on this topic are beyond the scope of this review. Over the last decade, amyloid beta targeting immunotherapy has been at the fore of drug discovery for $\mathrm{AD}$. Some progress has been made as have missteps. In this review we will describe the past, present and future directions of amyloid beta targeting immunotherapy and its potential as a disease modifying therapy for AD.

\section{APP PROCESSING AND A $\beta$ ACCUMULATION}

$\mathrm{A} \beta$ peptide has been the therapeutic target of a number of high profile drug discovery programmes, including both active and passive immunotherapy for $\mathrm{AD}$, based on the "Amyloid Hypothesis" [see for details review hardy and Selkoe (Selkoe and Hardy, 2016)]. A $\beta$ is produced from the cleavage of the amyloid precursor protein (APP) by cysteine proteases and secretase activity (Perez-Garmendia and Gevorkian, 2013; PerezGarmendia et al., 2014). APP is a type-I membrane protein with its amino $\mathrm{N}$-terminus in the lumen/extracellular space and its carboxyl C-terminus in the cytosol, which can be proteolytically processed by three secretases called $\alpha-, \beta$-, and $\gamma$-secretase (3). The process is summarized in Figure 1. The non-amyloidogenic pathway is initiated by $\alpha$-secretase releasing $\operatorname{sAPP} \alpha$ into the intracellular space. The resulting CTF- $\alpha$ fragment is cleaved by $\gamma$-secretase in the intermembrane space resulting in the AICD and p3 fragments, which do not form plaques. The amyloidogenic pathway is initiated by $\beta$-secretase and results in release of sAPP $\beta$ and generation of a carboxy-terminal fragment (C99), which is cleaved by $\gamma$-secretase and generates monomeric $A \beta$ species including $A \beta 1-38, A \beta 1-40$, and $A \beta 1-42$; the latter fragment is prone to aggregate and forms oligomers and fibrils. APP processing occurs naturally in the process of aging, and the resulting peptides are cleared from the brain through bulk flow along the perivascular pathway (Morris et al., 2014). Increasing evidence supports that excessive production or lack of clearance can result aberrant extracellular and intraneuronal accumulation and deposition of $A \beta$, followed by dysfunction of synapses and eventual loss of neurons. This imbalance between the clearance and production of $\mathrm{A} \beta$ peptides forms a critical part of the "Amyloid Hypothesis" (Selkoe and Hardy, 2016). The extracellular plaques exist in two main forms: neuritic or diffuse plaques. Neuritic plaques have a crystalline structure and are able to bind the dye Congo red. These congophilic extracellular deposits of $\mathrm{A} \beta$ are associated with degenerative neural structures (dendritic neurites) and are the harbinger for neuroinflammation, as evidenced by an abundance of microglia in the core of the plaque and astrocytes at the periphery (Perl, 2010). Diffuse plaques are not able to bind Congo red and do not disrupt the neuropil. These diffuse plaques are seen in aged persons and are generally not associated with dementia (Morris et al., 1996). Different sizes and self-assembly species of $A \beta$ peptide have been described, with $A \beta 1-42$ typically considered to be the type most prone to aggregate, but there is good evidence that $A \beta 1-43$ for example as well as other modified $A \beta$ species, are more prone to aggregation and more neurotoxic (Saito et al., 2011). The monomers of $A \beta$ peptides can form oligomers, which become larger protofibrils, leading to fibril and plaque formation. It is still not entirely clear how long oligomers of these peptides need to be present in the brains of subjects before they deposit as the insoluble amyloid plaques, but increasing evidence suggests that neuronal toxicity depends on the molecular composition, rather than the amount of these peptides (Piccini et al., 2005).

In addition to most commonly described $A \beta 1-40$ and $A \beta 1$ 42 peptides starting with an aspartate at position 1 , several other $\mathrm{A} \beta$ peptides species have been identified in $\mathrm{AD}$ brains (Bayer and Wirths, 2014). The heterogeneous pool of peptides is a result of post-translational modifications, including isomerization and racemization of aspartates, cyclization of $\mathrm{N}$-terminal glutamates, oxidation of methionine and abundant $\mathrm{N}$ - and C-terminal truncations. See Figure 1 for a schematic overview of the most common modifications. C-terminal truncations may occur in the presence of metalloproteinases (Cabrera et al., 2018) resulting in a more soluble and less aggregation prone peptides. Examples of C-truncated peptides include $A \beta 1-38$ and $A \beta 1-37$, which are predominantly observed in the vasculature (Moro et al., 2012; Reinert et al., 2016). Oxidation and nitration, are likely induced by the inflammatory milieu (Kummer and Heneka, 2014) and N-terminal truncations arise from the combined actions of $\mathrm{A} \beta$-degrading enzymes, such as neprylisin, insulin degrading-, and endothelin converting-enzymes which are commonly found in human $\mathrm{AD}$, but not in transgenic mice (Kalback et al., 2002; Schieb et al., 2011). An example of an $\mathrm{N}$-terminal modified peptide is $\mathrm{A} \beta$ modified by pyroglutamate (A $\beta p E 3$ or $A \beta p E 11)$ (Jawhar et al., 2011). These peptides have been found in early stages of $\mathrm{AD}$, prior to clinical symptoms. Pyroglutamation occurs after dehydration of glutamate residues, which results in the loss of a negative charge that increases the $\beta$-sheet content, aggregation propensity, hydrophobicity, and resistance to enzymatic degradation of the $A \beta$ fragments (He and Barrow, 1999). It mainly localizes in the core of amyloid plaques, suggesting a possible role in inducing and facilitating $A \beta$ oligomerization and accumulation (Dammers et al., 2017). One of the first $A \beta$ peptides reported was the $\mathrm{N}$-terminal truncated A $\beta 4-42$ (Kummer and Heneka, 2014), which is abundant in the hippocampus and cortex of sporadic $\mathrm{AD}$, familiar $\mathrm{AD}$ and vascular dementia (Lewis et al., 2006; Portelius et al., 2010). The relevance for this modification in neuropathology is emphasized in transgenic mice expressing A $\beta 4-42$ that develop CA1 neuronal loss and age-related spatial memory deficits without plaque formation (Bouter et al., 2013). These peptides have become a desirable therapeutic target for AD (Perez-Garmendia and Gevorkian, 2013; Cynis et al., 2016). NT4X-167, an experimental antibody that recognizes phenylalanine at position four of $A \beta 4-x$ on monomeric and oligomeric $\mathrm{A} \beta 4-\mathrm{x}$ peptides rescued $\mathrm{A} \beta 4-42$ induced neuron death in vitro and in vivo (Antonios et al., 2013, 2015). Supportive immunohistological studies using NT4X-167 detected only a 


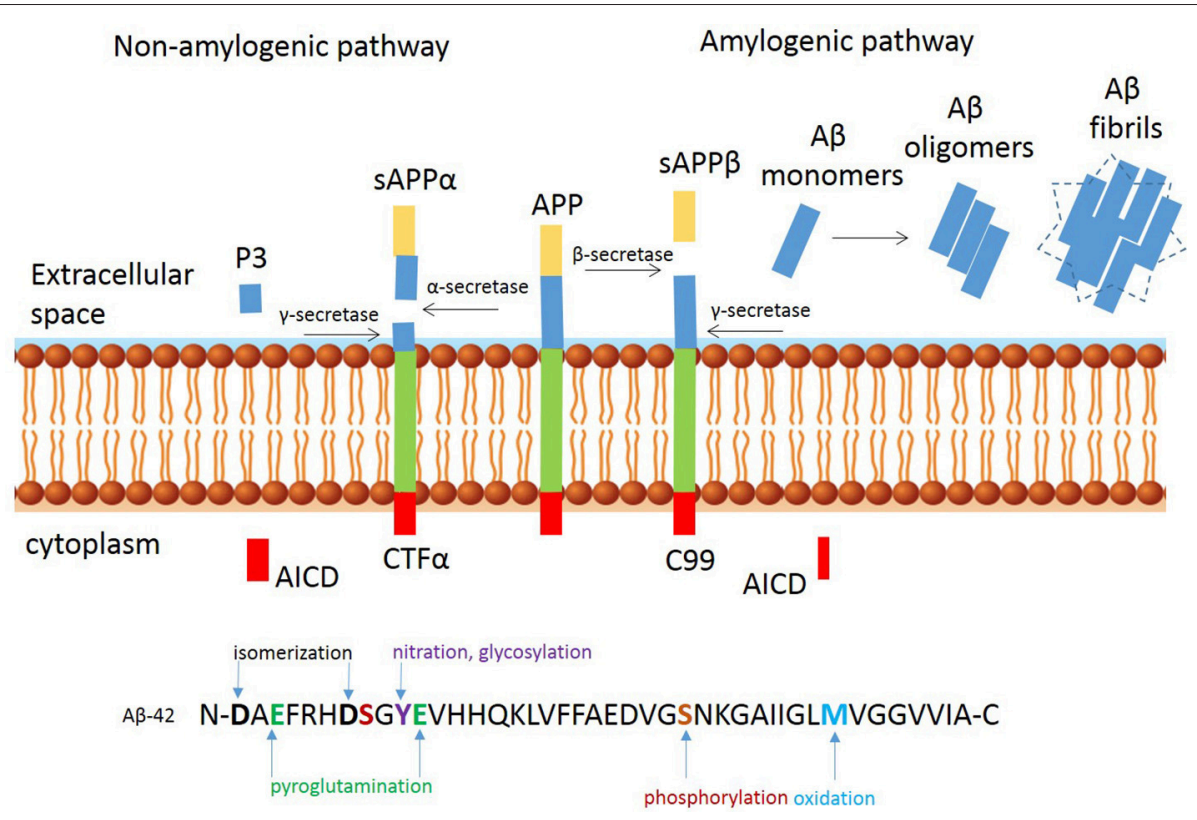

FIGURE 1 | Proteolytic processing of amyloid precursor protein. Proteolytic processing of APP within the non-amyloidogenic (left) and amyloidogenic (right) pathways and post translational modifications of $\mathrm{A} \beta-42$ peptide at the $\mathrm{N}$-and $\mathrm{C}$-terminus.

minor fraction of plaques in brain from sporadic and familial AD patients and preferentially reacts with intraneuronal $A \beta$, rather than plaques in young $5 \mathrm{xFAD}$ mice. However, this antibody also recognizes $\mathrm{A} \beta \mathrm{pE} 3-\mathrm{x}$ peptides and is therefore not suitable for accurate measurement of the abundance and distribution of $A \beta 4-x$ peptides. Polyclonal antibodies that selectively bind the six-amino acid peptide (FRHDSG) corresponding to residues 49 of the $\mathrm{A} \beta$ peptide sequence have shown that the distribution of $A \beta 4-x$ peptides is restricted largely to amyloid plaque cores and as $\mathrm{A} \beta$ deposits found around cerebral blood vessels termed cerebral amyloid angiopathy (CAA) whereas diffuse amyloid deposits were negative for $\mathrm{N}$-truncated peptides. These observations were made in brain sections of both patients with sporadic $\mathrm{AD}$ and at very early time points in two $\mathrm{AD}$ mouse models (Casas et al., 2004; Wirths et al., 2017). These observations confirm mass spectrometry studies from 30 years ago, indicating a high percentage of $\mathrm{N}$-terminal truncated peptides in plaques, while full length amyloid peptides are more abundant in the vasculature (Masters et al., 1985; Miller et al., 1993). In the same vain, others have shown that a plaque binding antibody targeting a modified $A \beta p E 3-42$, showed robust clearance of preexisting plaque (Demattos et al., 2012), and both passive and active immunization with $\mathrm{A} \beta \mathrm{pE} 3$ reactive antibodies have also shown to be success for clearance of plaque in APPswe/PS1 $\triangle \mathrm{E} 9$ mice (Frost et al., 2015).

Although AD pathology has been mostly linked to insoluble, aggregated amyloid, soluble species of $A \beta$ also contribute to neuronal dysfunction. Soluble oligomeric species of $A \beta$ have been demonstrated to impair hippocampal LTP (Lei et al., 2016). These soluble species of $A \beta$ can bind to neuronal receptors expressed on synapses, such as N-methyl-D-aspartate receptor (NMDA-R), disrupt glutamatergic/GABAergic balance, and lead to neuronal dysfunction or eventual death. Given the observation that metalloproteinases may be implicated in generating C-terminal modifications, it is tempting to speculate a role for inflammation in increasing the levels of soluble amyloid. Studies using NMDA$\mathrm{R}$ antagonists, such as memantine, to prevent the disruption of synaptic plasticity by soluble $\mathrm{A} \beta$ (Hu et al., 2009; Freir et al., 2011), provide additional supportive evidence for the benefits of targeting these peptides as a therapy. It has also been suggested that conformational changes of the receptor, possibly due to increased oxidative stress, rather than flow of ions through the channel, is required for $\mathrm{A} \beta$-mediated synaptic depression (Kessels et al., 2013).

\section{ANTI-A $\beta$ IMMUNOTHERAPY}

Targeting A $\beta$ by active or passive vaccination has received much interest from both the pharmaceutical industry and academia in the past two decades. Active vaccination is defined by introducing an exogenous substance to stimulate the immune system to mount a response. The type of immune response can be influenced by certain adjuvants to promote a humoral, or antibody response. Passive vaccination involves the introduction of antibodies directly into an animal or person to produce a benefit similar to that of active vaccination. Numerous passive and active immunotherapeutic approaches were developed for AD, summarized by Brody and Holtzman (2008). In 1999, Dale Schenk et al. published a landmark paper on active A $\beta$ vaccination to prevent and treat amyloid load and cognitive decline in experimental AD models. The active vaccine (AN1792) was tested in phase 2 a clinical trials, but when $6 \%$ of patients treated developed encephalitis the development of AN1792 was terminated, although follow-up assessment of treated 


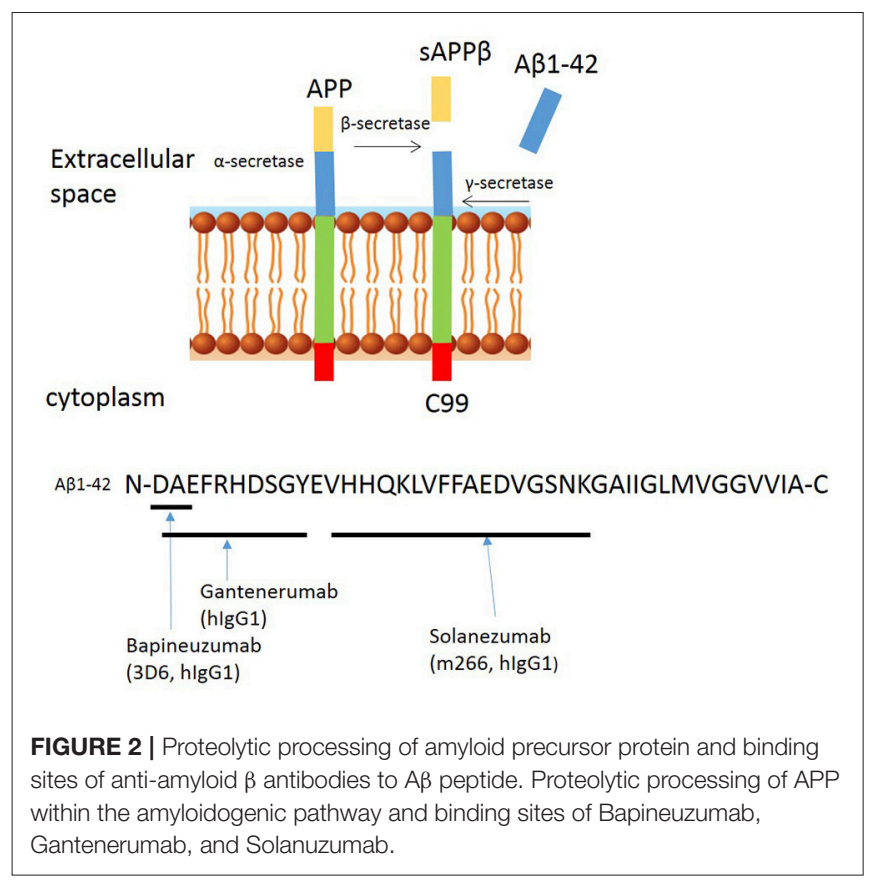

patients continued (Nicoll et al., 2003; Maarouf et al., 2010). The learnings from these initial efforts at active vaccination continue are still being absorbed by the field, and additional active vaccination programs have commenced in the last few years with development of CAD106 being the most advanced (NCT02565511).

Passive immunization approaches using monoclonal antibodies specifically targeting different epitopes of the $A \beta$ peptide have received increasing interest. These antibodies include the widely described Bapineuzumab, Gantenerumab, and Solanezumab, which were all tested in phase 3 clinical trials aiming to become the first disease-modifying therapy for $\mathrm{AD}$. The binding sites of these antibodies are summarized in Figure 2.

Bapineuzumab (AAB-001) is a humanized IgG1 anti-A $\beta$ antibody, derived from the murine monoclonal antibody 3D6 (IgG2b), originally developed by Elan. Bapineuzumab binds $A \beta$ at the $\mathrm{N}$-terminal residues in a monomeric helical conformation (Miles et al., 2013), explaining its selective binding to fibrillar and soluble $A \beta$ species but not truncated peptides (Feinberg et al., 2014). Preclinical studies show that systemic administration of 3D6 lowers plaque load in 9 month old PDAPP mice and levels persist for nearly 1 month in disease-affected brain regions of transgenic PDAPP mice, suggesting penetration across the BBB (Bard et al., 2012). In phase 1 trials, the safety, tolerability, and pharmacokinetics of Bapineuzumab was assessed in patients with mild to moderate $\mathrm{AD}$. Three of the patients receiving the highest dose $(5 \mathrm{mg} / \mathrm{kg})$ developed abnormalities as assessed by magnetic resonance imaging (MRI), consistent with vasogenic edema, but it was concluded that the treatment appeared overall safe and well-tolerated. In phase 2 trials (NCT00606476), Bapineuzumab treatment resulted in a greater reduction of amyloid as observed by positron-emission tomographic amyloid imaging using Pittsburgh compound B (PIB-PET) (Rinne et al., 2010). However, there were side effects, including vasogenic edemas (termed amyloid-related imaging abnormalities, ARIAE) and higher frequencies of micro-hemorrhages compared to control groups (Salloway et al., 2009). ARIA-E, is an increase in extracellular volume due to an increase in the permeability of the $\mathrm{BBB}$ to serum proteins. ARIA-E shares characteristics with CAA as both occur in the leptomeninges, gray and white matter (Sperling et al., 2011), and both have an association with the ApoE4 mutation, which increases the risk of developing ARIA-E (Strittmatter et al., 1993); based on these observations, the highest dose $(5 \mathrm{mg} / \mathrm{kg})$ was abandoned. Bapineuzumab was tested in phase 3 clinical trials (NCT00575055 and NCT00574132). Both studies were terminated early finding no difference in cognitive decline between the Bapineuzumab and placebo groups (Vandenberghe et al., 2016). Biomarker analyses indicated that Bapineuzumab engaged its target but had no benefit.

Solanezumab (also known as LY2062430), is a humanized IgG1 version of the murine antibody m266, developed by Eli Lilly and Company. This monoclonal antibody targets residues 13-28 (see Figure 1), a mid-terminal epitope of $A \beta$ (Crespi et al., 2015). Solanezumab is unable to bind fibrillary $A \beta$ but instead binds to circulating and soluble $A \beta$ species (Hefti et al., 2013). Preclinical studies showed that systemic administration of $\mathrm{m} 266$ removes soluble species of $\mathrm{A} \beta$ that are directly toxic to synaptic function, without affecting amyloid plaques (Dodart et al., 2002). Subsequent, phase 1 and 2 clinical trials demonstrated a good safety profile and encouraging indications on both cerebrospinal and plasma biomarkers, including levels of $A \beta 40, A \beta 42$, and plasma pyro-Glu $A \beta$ (Imbimbo et al., 2012). The phase 3 trials of this drug (EXPEDITION 1 and EXPEDITION 2) showed no significant improvement in primary outcomes, despite only $0.9 \%$ ARIAs with Solanezumab and $0.4 \%$ with placebo (Doody et al., 2014). Another phase 3 trial (EXPEDITION 3) was carried out, involving patients with mild $\mathrm{AD}$ but has also since been terminated due to failure to reach primary endpoints and no significant difference between Solanezumab and placebo.

Gantenerumab is fully human IgG1 antibody, which binds to a conformational epitope of $A \beta$ consisting both $\mathrm{N}$ terminal and central amino acids (Figure 1). It prefers binding to the fibrillary forms of the protein (Novakovic et al., 2013). Preclinical studies reveal that Gantenerumab recruits microglia to reduce amyloid load through antibody mediated phagocytosis, and prevents new plaque formation. This antibody does not alter systemic levels of $A \beta$ which suggested that clearance of soluble $A \beta$ is undisturbed (Bohrmann et al., 2012). In the phase 3 multi-center, randomized, double-blind, placebo controlled trial SCarlet RoAD (Scheltens, 2015). Gantenerumab showed target engagement, resulting in clearance of plaques, and reduced levels of phosphorylated tau in the spinal cord fluid, but the trial was abandoned in December 2014, likely as a result of ARIAs and abandonment of the top dose (Piazza and Winblad, 2016). Unperturbed, two new phase 1 trials of higher doses of Gantenerumab have been announced in 2016, and in 2017 two new phase 3 trials in prodromal AD were announced. 


\section{What Have We Learned From These Trials?}

The phase 3 clinical trial of passive immunotherapy targeting amyloid were disappointing given the initial success in experimental models, but have increased our basic understanding of AD. Numerous hypotheses have been generated to explain the failed primary endpoints. These include, but are not limited to (a) the role of antibody effector function and promoting inflammation through Fc receptors, (b) the optimal timing of the therapy, and (c) target engagement and antibody specificity.

\section{Antibody Effector Function}

Experimental models of $\mathrm{AD}$ and observations from clinical trials have provided evidence that IgG Fc $\gamma$ Receptors $(\mathrm{Fc} \gamma \mathrm{R})$ are largely responsible for amyloid clearance following immunotherapy, mediating activation of microglia, and antibody-mediated phagocytosis, but these effects are also associated with increased inflammation and vascular side effects (Wilcock and Colton, 2009). Human IgG1 and mouse IgG2a are the preferred isotype to promote amyloid clearance, due to their higher affinity to activating $\mathrm{Fc} \gamma \mathrm{Rs}$ as compared to other IgG subclasses, resulting in more effective phagocytosis and pro-inflammatory cytokine production by the effector cell (Bruhns, 2012). Both microglial activation and micro-hemorrhage are prevented when anti-A $\beta$ antibodies are deglycosylated, confirming the critical role of Fc $\gamma$ Rs in vascular side effects, at least for antibodies binding the N-terminal epitope of A $\beta$ (Wilcock et al., 2006; Freeman et al., 2012). To study the role of antibody effector function further, we directly compared three antibodies in the same pre-clinical model, with the same IgG2a effector function, for their ability to clear plaques and induce inflammation in the brain (Fuller et al., 2015). The results suggest that the ability of an antibody to safely clear plaques in experimental models is dependent on both the epitope and affinity of the antibody, rather than antibody effector function only. The effector function of IgG can be modified by antibody engineering and this approach has already resulted in a number of second generation amyloidspecific antibodies. Crenezumab (MABT5102A, RG7412) is a humanized IgG4 antibody that can bind to multiple forms of $\mathrm{A} \beta$, and is selective for the mid terminus (Crespi et al., 2015). Using an IgG4 subclass reduces affinity for activating Fc $\gamma$ Rs and therefore a reduced microglial activation and reduced vascular damage (Bruhns, 2012). Indeed, doses up to $15 \mathrm{mg} / \mathrm{kg}$ are welltolerated in experimental models and AD patients (Adolfsson et al., 2012). Despite these modifications, the ABBY phase 2 trial of Crenezumab, failed to reach its primary endpoints of an improvement in ADAS-Cog12 and CDR-SB score (Soejitno et al., 2015). Possible reasons for lack of efficacy could have been due to the inclusion of patients with moderate $\mathrm{AD}$ rather than mild $\mathrm{AD}$, who showed improved cognition. The ongoing CREAD study was designed to test the efficacy of Crenezumab in patients with mild $\mathrm{AD}$, with an estimated study completion date of July 2021. Another antibody, GSK933776, is a humanized IgG1 monoclonal antibody directed against the $\mathrm{N}$-terminus of the $A \beta$ peptide (aa1-5) (Novakovic et al., 2013). The Fc part of this monoclonal antibody is engineered by introducing alanine at position 235 and 237 in the constant region of the heavy chain. Phase 1 trials have been completed (Andreasen et al.,
2015) and total levels of circulating $A \beta$ increased and levels of free $A \beta$ in the CSF decreased implying that this Fc-engineered anti-A $\beta$ mAb engaged its target in plasma and CSF without causing brain ARIA-E/H in patients with mild $\mathrm{AD}$ or mild cognitive impairment (Leyhe et al., 2014; Andreasen et al., 2015). A phase 2, proof-of-concept study (NCT01342926), evaluated the effects of GSK933776 in patients with Dry Age related Macular degeneration (AMD), but failed to meet its primary endpoint. As part of this study, MRI's were performed and 2/15 participants showed asymptomatic adverse events; a cerebral hemorrhage and a cerebral infarct, both in the $15 \mathrm{mg} / \mathrm{kg}$ group. Another antibody, AAB-003, is a humanized Fc engineered version of Bapineuzumab, co-developed by Janssen and Pfizer. To achieve this $\mathrm{Fc}$ effector function reduction, three amino acid mutation in the lower hinge region of Bapineuzumab were introduced, reducing the affinity to $\mathrm{F} c \gamma \mathrm{R}$ and reduced binding to complement C1q (unpublished Janssen data). The AAB-003 was tested in a first in human study and was safe and well-tolerated up to 8 $\mathrm{mg} / \mathrm{kg}$ in mild to moderate AD (Delnomdedieu et al., 2016). Asymptomatic and resolvable ARIA-E was observed after the first or second infusion of AAB-003, but the dose at which ARIA-E was observed was considerably higher compared to Bapineuzumab $(1 \mathrm{mg} / \mathrm{kg})$, a finding that supports the hypothesis that reducing Fc-receptor effector function may reduce the risk of ARIA associated with monoclonal antibodies targeting aggregated cerebral amyloid. Furthermore, another antibody, MEDI 1814 , is a high-affinity, fully human $\operatorname{IgG} 1 \lambda$ monoclonal antibody directed to the $\mathrm{C}$-terminus of $\mathrm{A} \beta 42$. This monoclonal antibody is designed to target monomeric $A \beta 42$ and not $A \beta 40$. Its effector function has been reduced with a triple mutation in its Fc tail. In rats and monkeys, MEDI1814 increased total A $\beta 42$ and decreased free $A \beta 42$ in the CSF, without changing $A \beta 40$ levels and no serious adverse events have been reported. None of the participants on drug in phase I had signs of either ARIA-H or ARIA-E (https://clinicaltrials.gov/ct2/show/NCT02036645). This antibody is being developed jointly by AstraZeneca and Eli Lilly.

\section{Timing of Therapy}

The disappointing results of $A \beta$ immunotherapy may be due to the doses of Bapineuzumab used in the studies, as well as the disease state combined with accurate diagnosis of $\mathrm{AD}$. It is estimated that $\sim 20 \%$ of patients in the Bapineuzumab trial had dementia, but not as a result of AD (Salloway et al., 2014). The gold standard method for diagnosing AD is histopathology on post-mortem tissue, but amyloid tracers, such as 18F-FDG and 11C-PiB PET have been developed and are now widely used, allowing analysis of plaque deposition during disease course and enrolling patients at earlier stage disease. A more diverse set of diagnostics can identify patients before amyloid plaques or tau tangles appear, which includes the use of CSF and plasma biomarkers that could be used to stratify patients for clinical trials. Examples of biomarkers include CSF levels of amyloid and tau or the more recent described inflammatory markers, including proteins of the complement pathway (Sattlecker et al., 2016) and neurofilament light chain (Lista et al., 2017). Identification of accurate and suitable fluid biomarkers requires more research, using longitudinal studies, 
which could be accelerated if data and biological samples from past and ongoing trials can be shared.

\section{Epitope and Target Engagement}

Target engagement is critical for drug discovery, and is determined by the specificity of the antibody, the ability to cross the $\mathrm{BBB}$, or a combination thereof. A number of active and passive immunization studies reached clinical trial, but failed in phase III studies, possibly due to lack of target engagement. While these studies showed that systemic administration of $A \beta 1-42$-targeting antibodies clear amyloid plaques, they do not prevent progressive cognitive decline in these patients (Holmes et al., 2008). DeMatthos et al. compared the murine IgG2b version of Bapineuzumab (3D6) at different stages of disease in experimental models (Demattos et al., 2012). The results showed that 3D6 is effective in preventing amyloid deposition in 9 month old PDAPP mice, while in 18-21 month aged PDAPP mice it fail to show any effect on amyloid load and showed an exacerbation of CAA-related microhemorrhage. The opposite effect was observed using an experimental antibody (mE8) that selectively recognizes a modified amino terminus of $A \beta p E 3-x$, which effectively cleared $A \beta$ by $F c \gamma R$-mediated phagocytosis without vascular side effects. It was postulated that antibodies which bind both aggregated and soluble $A \beta$ become saturated with soluble $A \beta$ in the CNS and thus cannot engage the deposited $A \beta$, whereas the plaque-specific $A \beta p E 3$ $\mathrm{x}$ antibodies robustly engages the deposited amyloid. These studies imply that antibody specificity may be most critical for successful development of $A \beta$ immunotherapy. Plaque removal may not be sufficient to rescue $\mathrm{AD}$ memory decline and as a consequence, the concept of using antibodies targeting amyloid (Benilova et al., 2012) plaques has been regarded as a potential risk factor as plaques may serve as reservoirs of toxic $A \beta$ peptides. Solanezumab, Crenezumab, Bapineuzumab, and Gantenerumab all bind to $A \beta$ plaques in post-mortem and APP transgenic mouse tissue, albeit at different levels (Bouter et al., 2015; Fuller et al., 2015). Bapineuzumab does not recognize $\mathrm{N}$-truncated or modified $A \beta$, while Solanezumab and Crenezumab do detect $\mathrm{N}$-terminally modified $\mathrm{A} \beta$ peptides $\mathrm{A} \beta 4-42$ and pyroglutamate modified A $33-42$ (Bouter et al., 2015). Immunotherapy using antibodies selective for $\mathrm{A} \beta 4-42$ and pyroglutamate-modified $A \beta 3-42$, or the C-terminal modified A $\beta 1-37 / 38$, without binding to plaques may be beneficial, although further understanding of the pathological relevance of truncated peptides is still required.

\section{CAN ANTIBODY ENGINEERING IMPROVE EFFICACY?}

Several second generation antibodies are in development that address target engagement, including antibodies with highly specific epitopes, which are summarized in Table $\mathbf{1}$ and Figure 3). BAN2401 is a humanized IgG1 antibody that selectively binds to large soluble $A \beta$ protofibrils (Lannfelt et al., 2014). Increased protofibril formation is found in a subgroup of $\mathrm{AD}$ patients, carrying the arctic APP mutation protein (E693G) (Nilsberth et al., 2001). This mutation leads to accelerated build-up of insoluble $A \beta$ deposits both intraneuronal and/or extracellularly. BAN2401 was developed by the biotech company BioArctic Neuroscience, and licensed to Eisai and Biogen who are jointly developing this antibody for therapeutic use. A clinical study demonstrated that the incidence of ARIA-E on MRI was similar to placebo. It is currently in a Phase II trial in subjects with early AD (NCT01767311; Logovinsky et al., 2016). Another A $\beta$ antibody, SAR255952 is a humanized monoclonal antibody also directed against soluble protofibrillar and fibrillar species of $A \beta$. This antibody is developed by Sanofi and is engineered on an IgG4 backbone which, like Crenezumab has low binding affinity for activating Fc $\gamma$ Rs on human microglia and no binding to complement C1q. A Phase 1 trial tested intravenous infusion and two doses of subcutaneous injection in patients with mild or moderate $\mathrm{AD}$ but no study results have been posted (NCT01485302). These studies highlight that stratification of patients carrying specific mutations in the APP gene may further contribute to the successful development of $A \beta$ immunotherapy. Finally, the novel fully human monoclonal antibody Aducanumab, originally developed by the Swiss biopharmaceutical company Neurimmune and licensed by Biogen for clinical development, is revitalizing the "amyloid cascade hypothesis" (Weitz and Town, 2016).

Aducanumab is a hIgG1 antibody and binds to the $\mathrm{N}$-terminus of A $\beta 3-6$. A unique feature of this antibody is its target: aggregated forms of the $A \beta$ protein, both the insoluble fibrils and the soluble oligomers. This characteristic could circumvent the problem where soluble forms of $A \beta$ may saturate antibodies such as Bapineuzumab meaning that plaques are not cleared effectively (Demattos et al., 2012). The antibody was originally discovered in elderly individuals with no signs of cognitive decline or cognitive decline with an unusually slow progression (Sevigny et al., 2016). Aducanumab was isolated by a process called "reverse translational medicine"1. This process starts by culturing B cells from the elderly population and screening for the ability of the culture supernatant to label $A \beta$ plaques in brain tissue from APP transgenic mice and/or $\mathrm{AD}$ patients. Positive $\mathrm{B}$ cells, were further screened to remove antibodies with cross-reactivity with full length APP (Sevigny et al., 2016). Preclinical studies show penetration across the BBB and histological analysis of the brain showed that Aducanumab bound $A \beta$ in both diffuse and compact plaques as well as $A \beta$ associated with CAA. A IgG2a murine chimeric ${ }^{c h}$ Aducanumab was used to determine the efficacy to clear cerebral $A \beta$ deposits. The results showed that $\mathrm{A} \beta 40$ and $\mathrm{A} \beta 42$ levels in the plasma brain were reduced in a dose-dependent manner. Thioflavin-S staining, which detect fibrillary amyloid, confirmed that Aducanumab reduced the number of plaques of all sizes and had no effect on vascular $A \beta$. Experiments further showed a significantly greater fraction of plaques that were at least $70 \%$ surrounded by microglia in the Aducanumab treated group than the PBS treated, suggesting Fc $\gamma \mathrm{R}$ mediated phagocytosis, which was confirmed by comparing plaque removal using an aglycosylated version of chAducanumab with a single N297Q point mutation to reduce Fc $\gamma$ R binding (Sevigny et al., 2016). A study by Kastanenka

\footnotetext{
$\overline{{ }^{1} \text { Biogen (2016). www.biogen.com. }}$
} 
TABLE 1 | Overview of amyloid $\beta$ specific antibodies.

\begin{tabular}{|c|c|c|c|c|c|c|}
\hline Antibody & Company & Current stage & $A \beta$ type bound & Epitope & Subclass & $\begin{array}{l}\text { ARIA-E Side } \\
\text { effects }\end{array}$ \\
\hline Solanezumab & Eli Lilly & $\begin{array}{l}\text { Phase } 3 \text { for mild } \\
\text { AD-terminated }\end{array}$ & Circulating and soluble $A \beta$ & $\begin{array}{l}\text { Mid terminal. Residues } \\
13-28\end{array}$ & $\lg G 1$ & No \\
\hline Gantenerumab & Roche & Phase 3 for mild AD_ongoing & Fibrillary forms & $\begin{array}{l}\text { Combined } \mathrm{N} \text { terminus and } \\
\text { mid-domain }\end{array}$ & $\lg G 1$ & Yes \\
\hline Crenezumab & Genentech/Roche & $\begin{array}{l}\text { CREAD study phase } 3 \text { for } \\
\text { mild AD-ongoing }\end{array}$ & $\begin{array}{l}\text { Soluble oligomeric, fibrillary, } \\
\text { and plaque }\end{array}$ & $\begin{array}{l}\text { Mid terminus, residues } \\
\text { 12-23 }\end{array}$ & $\lg G 4$ & No \\
\hline Bapineuzumab & $\begin{array}{l}\text { Elan/Pfizer and } \\
\text { Johnson \& Johnson }\end{array}$ & Phase 2 trial-terminated & Soluble and aggregated & $\begin{array}{l}\text { N terminus. } \\
\text { Residues 1-28 }\end{array}$ & $\lg G 1$ & Yes \\
\hline Aducanumab & Biogen & Phase 3 ENGAGE-ongoing & $\begin{array}{l}\text { Aggregated forms (insoluble } \\
\text { fibrils and soluble oligomers) }\end{array}$ & $\mathrm{N}$ terminus & $\lg G 1$ & Yes \\
\hline Ponezumab & Pfizer Inc & $\begin{array}{l}\text { Phase } 3 \text { trial for older } \\
\text { individuals who may be at risk } \\
\text { of memory loss-ongoing }\end{array}$ & Soluble and aggregated forms & $\begin{array}{l}\text { Residues } 33-40 \text { in } \\
\text { C terminus }\end{array}$ & $\lg G 2 a$ & No \\
\hline BAN2401 & $\begin{array}{l}\text { Eisai/BioArctic } \\
\text { Neuroscience }\end{array}$ & Phase 2b-ongoing & Soluble proto-fibrils & $\mathrm{N}$ terminal & & No \\
\hline SAR228810 & Sanofi & Phase 1 completed & Pre-fibrillary aggregates & & $\operatorname{lgG} 4$ & No \\
\hline GSK933776A & GSK & $\begin{array}{l}\text { Phase } 1 \text { completed, no } \\
\text { current plans to develop } \\
\text { further }\end{array}$ & & $\mathrm{N}$ terminal & $\lg G 1$ & No \\
\hline
\end{tabular}

et al. demonstrated how chronic administration of Aducanumab in 22 month old Tg2576 mice was able to ameliorate calcium overload and restore calcium homeostasis. Thus, this antibody may well-work by restoring the neuronal network function (Kastanenka et al., 2016). This study additionally shows that a readout of calcium overload may be a more appropriate readout for antibody efficacy than plaque reduction alone. Phase I studies followed to test the safety, tolerability and pharmacokinetics of Aducanumab (PRIME; ClinicalTrials.gov identifier NCT01677572) and no serious ARIA-E cases occurred in doses up $30 \mathrm{mg} / \mathrm{kg}$. All patients receiving the $60 \mathrm{mg} / \mathrm{kg}$ dose developed ARIA-E and/or microhaemorrhage. The phase I study included PET imaging showing dose and time depend reduction of $A \beta$ plaques, with the largest reduction in plaques in the $10 \mathrm{mg} / \mathrm{kg}^{-1}$ group after 1 year. Side effects were seen, most commonly Vasogenic Oedema, occurring early in treatment, but, none of these were serious and all were transient. Interestingly, analysis of the phase $1 \mathrm{~b}$ study shown that a lowering of cerebral $\mathrm{A} \beta$ slows cognitive decline by both the Mini Mental State Examination (MMSE) \& clinical Dementia rating. As a results of these studies Aducanumab received "Fast-Track Status" by the FDA and two phase 3 trials (ENGAGE \& EMERGE) are ongoing to investigate the efficacy in slowing cognitive decline in patients with early AD. Results are expected for mid-2018. It is also very encouraging that, the extent of amyloid reduction with Aducanumab is more marked than observed in the previous trials of Gantenerumab and Bapineuzumab (Rinne et al., 2010; Ostrowitzki et al., 2012).

Drug delivery to the brain is a major roadblock to treatment of $\mathrm{AD}$. Increased penetration can be achieved by antibody engineering and development of bispecific antibodies, for example targeting the transferring receptor expressed on the cerebral vasculature (Bien-Ly et al., 2014; Yu et al., 2014; Pardridge, 2016; Zuchero et al., 2016; see Table 2 for more

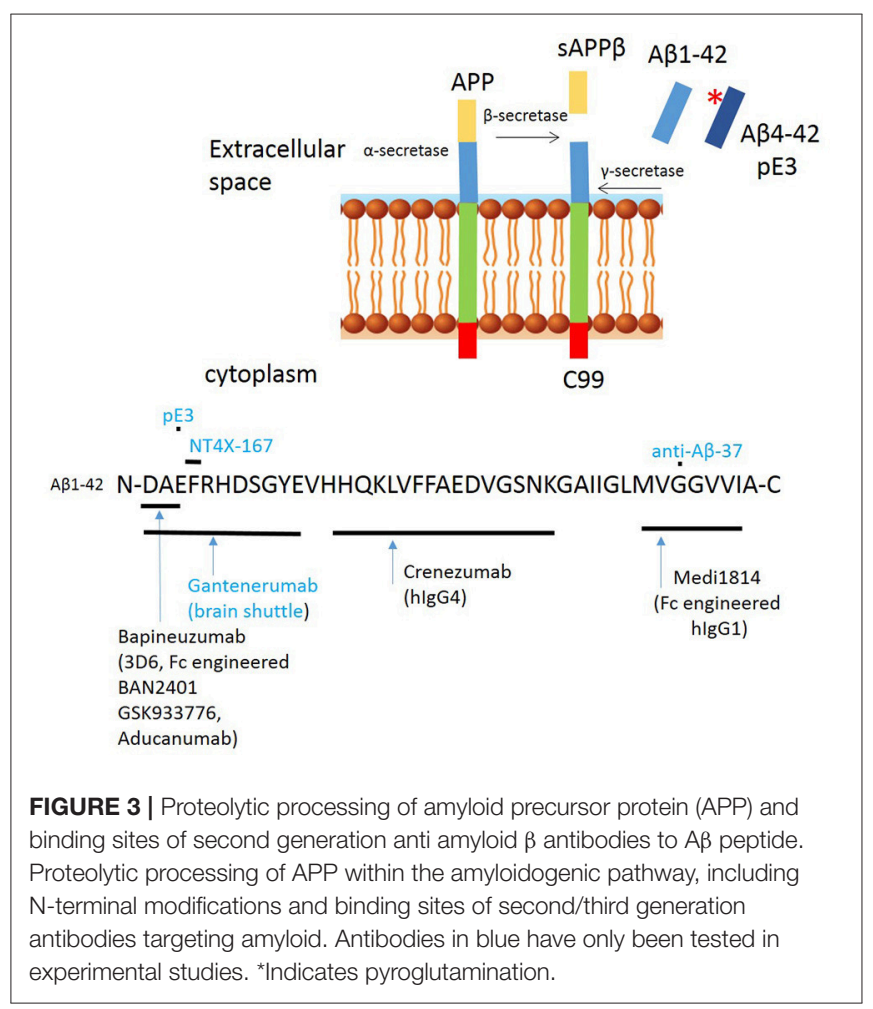

details). A single chain $\mathrm{Fv}(\mathrm{ScFv}$ ) antibody form of an antiamyloid antibody was fused to the $\mathrm{CH} 3$ domain of each heavy chain of a chimeric $(\mathrm{mAb})$ against the mouse transferrin receptor (TfR); subcutaneous administration of this tetravalent bispecific antibody resulted in 60\% reduction in amyloid (Sumbria et al., 2013). Roche recently developed a bispecific TfR-engineered 
TABLE 2 | Overview of antibody engineering approaches.

\begin{tabular}{|c|c|c|c|}
\hline Alteration & More Info & Effect & Examples \\
\hline Bispecific antibodies & $\begin{array}{l}\text { Antibodies targeting specific transport } \\
\text { receptors at BBB }\end{array}$ & $\begin{array}{l}\text { Increase penetration of therapeutic } \\
\text { antibody to cross BBB }\end{array}$ & $\begin{array}{l}\text { Anti-TfR/BACE1 Reduced A } \beta \text { in brain \& CSF dose dependently } \\
\text { (Yu et al., 2014). } \\
\text { cTfRMAb-ScFv-anti A } \beta+\text { anti-TfR Increased transport over BBB, } \\
\text { reduced A } \beta \text { load without increasing plasma A } \beta \text { and no CAA } \\
\text { (Sumbria et al., 2013). }\end{array}$ \\
\hline Glycosylation & E.g., addition of sialic acid & $\begin{array}{l}\text { Reduced efflux from brain. No change } \\
\text { on influx (Finke et al., 2017). }\end{array}$ & \\
\hline Fc-engineering & Triple mutation in $\mathrm{CH} 3$ & $\begin{array}{l}\text { Reduced effector function-Fc } \\
\text { Receptor and C1q binding }\end{array}$ & BAN AAB-003 MEDI \\
\hline
\end{tabular}

version of Gantenerumab, called the brain shuttle (Niewoehner et al., 2014). Experimental studies revealed that the effector function of the bispecific antibody is camouflaged when the bispecific antibody is bound to TfR but fully active when it binds amyloid, its CNS target. It was postulated that this dual behavior is due to steric hindrance of $\mathrm{Fc} \gamma \mathrm{R}$ on immune cells when TfR is bound. In this position, the two Fab arms of the IgG prevent the necessary proximity of the Fc region of the bispecific $\mathrm{mAb}$ to the $\mathrm{Fc} \gamma \mathrm{R}$ on effector cells, possibly interfering with $\mathrm{Fc} \gamma \mathrm{R}$ oligomerization. Once the bispecific $\mathrm{mAb}$ is released from the TfR into the CNS parenchyma, the $\mathrm{Fc} \gamma \mathrm{R}$ on recruited microglia can be engaged, allowing efficient clearance. These experimental data provide a valid strategy for the use of fully effector-functional mAbs that can be transported safely across the $\mathrm{BBB}$, but clinical validation is required.

Alternative approaches may include modification of the glycosylation of therapeutic antibodies (Finke et al., 2017). Using in vitro models of brain microvascular endothelial cells, Banks et al. showed that $\mathrm{mAb}$ lacking sialic acid have reduced $\mathrm{BBB}$ penetrance compared to mAbs carrying sialic acid residues. The influx of antibodies appeared largely insensitive to changes in their glycosylation states. Thus, sialylation may offer a means to reduce IgG drug efflux from the brain in conjunction with other techniques and biochemical modifications that increase influx. Sialylation may also confer other clinical benefits to AD patients, as sialylated IgG is reported to induce immune pathways with minimal inflammation (Li et al., 2017).

\section{IMMUNOTHERAPY BEYOND AMYLOID}

The development of second generation anti-amyloid antibodies are showing renewed interest in this therapeutic approach based on promising effects in clinical trials, but it is important to keep in mind the diverse underlying biological mechanism of $\mathrm{AD}$, including the role of established genetic and environmental risk factors. At least four disease mechanisms have been implicated in $\mathrm{AD}$ besides aggregation of beta amyloid and tau: neuroinflammation, vascular pathology, loss of protein homeostasis, and mitochondrial dysfunction. Immunotherapies targeting proteins other than amyloid are in clinicial development, including anti-tau mAbs. For example, AbbVie 8E12 recognizes extracellular, aggregated tau, and
Genentech humanized RO7105705, a mouse monoclonal antibody, which targets tau in the extracellular space, hoping to block the spread of toxic forms (Pedersen and Sigurdsson, 2015; Lee et al., 2016). Other approaches include peripheral administration of ApoE antibodies using experimental models, resulting in reduced ApoE levels in the brain, improved spatial learning performance in the Morris water maze and enhanced resting-state bilateral functional connectivity in different cortical regions. In vivo two-photon microscopic imaging demonstrated that ApoE specific antibodies are capable of reducing amyloid load. ApoE carriers have higher amyloid load in the parenchyma and cerebral vasculature and increased risk of cardiovascular disease and inflammation. It is now well-accepted that inflammation has a key role in sporadic $\mathrm{AD}$ and it is hypothesized that the APOE- $\varepsilon 4$ allele, modulates inflammation in both the periphery and the brain (Whalley et al., 2006; Harold et al., 2009; Hollingworth et al., 2011; Benitez et al., 2014).

Population studies have provided good evidence that a high cardiovascular risk profile reliably predicts progression from mild cognitive impairment to AD (Viticchi et al., 2015, 2017). Indeed, vascular cognitive impairment and dementia (VCID, or vascular dementia), occurs in as much as $40 \%$ of $\mathrm{AD}$ patients (Zekry et al., 2002), which may not be routinely taken into account in clinical trial design. An interesting experimental model for vascular dementia is hyperhomocysteinemia (HHcy), which can be induced by a diet deficient in folate, B6, and B12 and supplemented with excess methionine inducing diet (Sudduth et al., 2013). Elevated circulating levels of the sulfurcontaining amino acid homocysteine can lead to oxidative stress, pro-inflammatory cytokine production, increased levels of inducible nitric oxide (NO) synthase (iNOS), and cerebral vascular dysfunction (Faraci and Lentz, 2004; Kamat et al., 2015). Weekman et al. tested the efficacy of $A \beta$ immunotherapy in APP/PS1 mice fed the HHcy or control diet (Weekman et al., 2016). Intriguingly, systemic 3D6 (IgG2a) treatment failed to improve cognition in APP/PS1 mice on the HHcy diet, despite reduced levels of total $A \beta$ levels. This lack of cognitive benefits could be due to the increase in the number of microhemorrhages seen in the 3D6-treated HHcy mice compared with the 3D6 or HHcy controls, or the increased levels of CAA. The lack of cognitive effects was not associated with an overt cytokine response by microglia, suggesting alternative underlying mechanism. These finding could be of importance as VCID is 
asymptomatic and may be a common co-morbidity in mild AD. $\mathrm{AD}$ pathology is characterized by the presence of $\mathrm{A} \beta$ oligomers and fibers, which are typically found in the aging brain. There are numerous endogenous proteins and metal ions that interact with $A \beta$ and influence its assembly process both in vitro and in animal models. One of these proteins is albumin, which prevents fibrillization upon binding (Bode et al., 2018). The ability of albumin to sequester $A \beta$ may explain why $A \beta$ deposits are not observed in the peripheral vasculature, even though plasma levels of $\mathrm{A} ß$ are comparable to CSF (Bode et al., 2018). Albumin plays a role in clearing amyloid from the brain and the use of albumin as a therapeutic approach has shown encouraging effects in clinical trial (Boada et al., 2017). Interestingly, cholesterol and fatty acids prevent albumin from binding to amyloid, possibly further explaining cardiovascular disease as a link to AD (Bode et al., 2018).

Systemic inflammation contributes to an altered CNS microenvironment, switching primed microglial into a more aggressive phenotype, changes to the BBB permeability and increased expression of $\mathrm{Fc} \gamma \mathrm{Rs}$ on microglia and perivascular macrophages (Teeling and Perry, 2009; Lunnon et al., 2011). Tucsek et al. made similar observations when comparing the effect of a high fat diet showed increased BBB leakage and levels of IgG in the hippocampus of aged mice, but not young mice (Tucsek et al., 2014). These changes were accompanied by increased transcriptional levels of pro-inflammatory cytokines. Collectively, these experimental studies imply that that low grade systemic inflammation, induced by diet or chronic bacterial infection (Ide et al., 2016), alters the microenvironment of the brain and thereby, possibly the efficacy of amyloid immunotherapy; biomarkers of systemic inflammation may be a useful addition to stratify patients in future clinical trials.

\section{REFERENCES}

Adolfsson, O., Pihlgren, M., Toni, N., Varisco, Y., Buccarello, A. L., Antoniello, K., et al. (2012). An effector-reduced anti- $\beta$-amyloid (A $\beta$ ) antibody with unique $\mathrm{a} \beta$ binding properties promotes neuroprotection and glial engulfment of $A \beta$. J. Neurosci. 32, 9677-9689. doi: 10.1523/JNEUROSCI.4742-11.2012

Andreasen, N., Simeoni, M., Ostlund, H., Lisjo, P. I., Fladby, T., Loercher, A. E., et al. (2015). First administration of the Fc-attenuated anti- $\beta$ amyloid antibody GSK933776 to patients with mild Alzheimer's disease: a randomized, placebocontrolled study. PLoS ONE 10:e0098153. doi: 10.1371/journal.pone.0098153

Antonios, G., Borgers, H., Richard, B. C., Brauß, A., Meißner, J., Weggen, S., et al. (2015). Alzheimer therapy with an antibody against N-terminal A $\beta$ 4-X and pyroglutamate A $\beta$ 3-X. Sci. Rep. 5:17338. doi: 10.1038/srep 17338

Antonios, G., Saiepour, N., Bouter, Y., Richard, B. C., Paetau, A., VerkkoniemiAhola, A., et al. (2013). N-truncated A $\beta$ starting with position four: early intraneuronal accumulation and rescue of toxicity using NT4X167, a novel monoclonal antibody. Acta Neuropathol. Commun. 1:56. doi: 10.1186/2051-5960-1-56

Bard, F., Fox, M., Friedrich, S., Seubert, P., Schenk, D., Kinney, G. G., et al. (2012). Sustained levels of antibodies against $A \beta$ in amyloid-rich regions of the CNS following intravenous dosing in human APP transgenic mice. Exp. Neurol. 238, 38-43. doi: 10.1016/j.expneurol.2012.07.022

Bayer, T.A., and Wirths, O. (2014). Focusing the amyloid cascade hypothesis on $\mathrm{N}$-truncated Abeta peptides as drug targets against Alzheimer's disease. Acta Neuropathol 127, 787-801. doi: 10.1007/s00401-014-1287-x

\section{CONCLUSION}

The clinical trials to date have shown that immunotherapy against $\mathrm{A} \beta$ is able to clear plaques from the brains of $\mathrm{AD}$ patients. However, they have also highlighted the danger of immune activation within the CNS, as a result of neuroinflammation and vasogenic oedema. Lessons can be learnt from cancer immunotherapy where monoclonal antibodies have been engineered to improve efficacy and allowing higher antibody penetration with fewer side effects. In addition, antibody specificity appears critical as shown in recent data using the fully human antibody Aducanumab, which selectively binds to the aggregated form of amyloid and encouraging results in preclinical models using antibodies that selectively bind to truncated amyloid peptides. To allow the production of safe and effective CNS immunotherapies it is essential to understand the underlying biological mechanisms that can contribute to antibody efficacy, which may include genetics and environmental factors. This would allow the selection the most appropriate antibody isotypes or mutants minimizing the risk of adverse events.

\section{AUTHOR CONTRIBUTIONS}

IS: contributed to writing the manuscript; RE: contributed to writing the manuscript; AA: contributed to writing and reviewing the manuscript; JT: contributed to writing and reviewing the manuscript.

\section{ACKNOWLEDGMENTS}

We thank Dr. Allan Jensen for critically reading the manuscript.

Benilova, I., Karran, E., and De Strooper, B. (2012). The toxic A $\beta$ oligomer and Alzheimer's disease: an emperor in need of clothes. Nat. Neurosci. 15, 349-357. doi: 10.1038/nn.3028

Benitez, B. A., Jin, S. C., Guerreiro, R., Graham, R., Lord, J., Harold, D., et al. (2014). Missense variant in TREML2 protects against Alzheimer's disease. Neurobiol. Aging 35, 1510.e1519-e1526. doi: 10.1016/j.neurobiolaging.2013.12.010

Bien-Ly, N., Yu, Y. J., Bumbaca, D., Elstrott, J., Boswell, C. A., Zhang, Y., et al. (2014). Transferrin receptor (TfR) trafficking determines brain uptake of TfR antibody affinity variants. J. Exp. Med. 211, 233-244. doi: 10.1084/jem.20131660

Boada, M., Anaya, F., Ortiz, P., Olazaran, J., Shua-Haim, J. R., Obisesan, T. O., et al. (2017). Efficacy and safety of plasma exchange with $5 \%$ albumin to modify cerebrospinal fluid and plasma amyloid- $\beta$ concentrations and cognition outcomes in Alzheimer's disease patients: a multicenter, randomized, controlled clinical trial. J. Alzheimers Dis. 56, 129-143. doi: 10.3233/JAD-160565

Bode, D. C., Stanyon, H. F., Hirani, T., Baker, M. D., Nield, J., and Viles, J. H. (2018). Serum albumin's protective inhibition of amyloid- $\beta$ fiber formation is suppressed by cholesterol, fatty acids and warfarin. J. Mol. Biol. 430, 919-934. doi: 10.1016/j.jmb.2018.01.008

Bohrmann, B., Baumann, K., Benz, J., Gerber, F., Huber, W., Knoflach, F., et al. (2012). Gantenerumab: a novel human anti-A $\beta$ antibody demonstrates sustained cerebral amyloid- $\beta$ binding and elicits cell-mediated removal of human amyloid- $\beta$. J. Alzheimers. Dis. 28, 49-69. doi: 10.3233/JAD-2011-110977

Bouter, Y., Dietrich, K., Wittnam, J. L., Rezaei-Ghaleh, N., Pillot, T., PapotCouturier, S., et al. (2013). N-truncated amyloid $\beta$ (A $\beta$ ) 4-42 forms stable 
aggregates and induces acute and long-lasting behavioral deficits. Acta Neuropathol. 126, 189-205. doi: 10.1007/s00401-013-1129-2

Bouter, Y., Lopez Noguerola, J. S., Tucholla, P., Crespi, G. A., Parker, M. W., Wiltfang, J., et al. (2015). A $\beta$ targets of the biosimilar antibodies of Bapineuzumab, Crenezumab, Solanezumab in comparison to an antibody against Ntruncated $\mathrm{A} \beta$ in sporadic Alzheimer disease cases and mouse models. Acta Neuropathol. 130, 713-729. doi: 10.1007/s00401-015-1489-x

Brody, D. L., and Holtzman, D. M. (2008). Active and passive immunotherapy for neurodegenerative disorders. Annu. Rev. Neurosci. 31, 175-193. doi: 10.1146/annurev.neuro.31.060407.125529

Bruhns, P. (2012). Properties of mouse and human IgG receptors and their contribution to disease models. Blood 119, 5640-5649. doi: 10.1182/blood-2012-01-380121

Cabrera, E., Mathews, P., Mezhericher, E., Beach, T. G., Deng, J., Neubert, T. A., et al. (2018). A $\beta$ truncated species: implications for brain clearance mechanisms and amyloid plaque deposition. Biochim. Biophys. Acta 1864, 208-225. doi: 10.1016/j.bbadis.2017.07.005

Carvalho, D. Z., St Louis, E. K., Knopman, D. S., Boeve, B. F., Lowe, V. J., Roberts, R. O., et al. (2018). Association of excessive daytime sleepiness with longitudinal $\beta$-amyloid accumulation in elderly persons without dementia. JAMA Neurol. doi: 10.1001/jamaneurol.2018.0049. [Epub ahed of print].

Casas, C., Sergeant, N., Itier, J. M., Blanchard, V., Wirths, O., Van Der Kolk, N., et al. (2004). Massive CA1/2 neuronal loss with intraneuronal and N-terminal truncated A $\beta 42$ accumulation in a novel Alzheimer transgenic model. Am. J. Pathol. 165, 1289-1300. doi: 10.1016/S0002-9440(10)63388-3

Crespi, G. A., Hermans, S. J., Parker, M. W., and Miles, L. A. (2015). Molecular basis for mid-region amyloid- $\beta$ capture by leading Alzheimer's disease immunotherapies. Sci. Rep. 5:9649. doi: 10.1038/srep09649

Cummings, J., Lee, G., Mortsdorf, T., Ritter, A., and Zhong, K. (2017). Alzheimer's disease drug development pipeline: 2017. Alzheimers Dement. 3, 367-384. doi: 10.1016/j.trci.2017.05.002

Cummings, J. L., Morstorf, T., and Zhong, K. (2014). Alzheimer's disease drugdevelopment pipeline: few candidates, frequent failures. Alzheimers Res. Ther. 6:37. doi: 10.1186/alzrt269

Cynis, H., Frost, J. L., Crehan, H., and Lemere, C. A. (2016). Immunotherapy targeting pyroglutamate- $3 \mathrm{~A} \beta$ : prospects and challenges. Mol. Neurodegener. 11:48. doi: 10.1186/s13024-016-0115-2

Dammers, C., Schwarten, M., Buell, A. K., and Willbold, D. (2017). Pyroglutamate-modified $A \beta$ (3-42) affects aggregation kinetics of $A \beta$ (142) by accelerating primary and secondary pathways. Chem. Sci. 8, 4996-5004. doi: 10.1039/C6SC04797A

Delnomdedieu, M., Duvvuri, S., Li, D. J., Atassi, N., Lu, M., Brashear, H. R., et al. (2016). First-In-Human safety and long-term exposure data for AAB-003 (PF05236812) and biomarkers after intravenous infusions of escalating doses in patients with mild to moderate Alzheimer's disease. Alzheimers Res. Ther. 8:12. doi: 10.1186/s13195-016-0177-y

Demattos, R. B., Lu, J., Tang, Y., Racke, M. M., Delong, C. A., Tzaferis, J. A., et al. (2012). A plaque-specific antibody clears existing $\beta$ amyloid plaques in Alzheimer's disease mice. Neuron 76, 908-920. doi: 10.1016/j.neuron.2012.10.029

Diekelmann, S., Wilhelm, I., and Born, J. (2009). The whats and whens of sleep-dependent memory consolidation. Sleep Med. Rev. 13, 309-321. doi: 10.1016/j.smrv.2008.08.002

Dodart, J. C., Bales, K. R., Gannon, K. S., Greene, S. J., Demattos, R. B., Mathis, C., et al. (2002). Immunization reverses memory deficits without reducing brain a $\beta$ burden in Alzheimer's disease model. Nat. Neurosci. 5, 452-457. doi: $10.1038 / \mathrm{nn} 842$

Doody, R. S., Thomas, R. G., Farlow, M., Iwatsubo, T., Vellas, B., Joffe, S., et al. (2014). Phase 3 trials of solanezumab for mild-to-moderate Alzheimer's disease. N. Engl. J. Med. 370, 311-321. doi: 10.1056/NEJMoa1312889

Faraci, F. M., and Lentz, S. R. (2004). Hyperhomocysteinemia, oxidative stress, and cerebral vascular dysfunction. Stroke 35, 345-347. doi: 10.1161/01.STR.0000115161.10646.67

Feinberg, H., Saldanha, J. W., Diep, L., Goel, A., Widom, A., Veldman, G. M., et al. (2014). Crystal structure reveals conservation of amyloid- $\beta$ conformation recognized by $3 \mathrm{D} 6$ following humanization to bapineuzumab. Alzheimers Res. Ther. 6:31. doi: 10.1186/alzrt261
Finke, J. M., Ayres, K. R., Brisbin, R. P., Hill, H. A., Wing, E. E., and Banks, W. A. (2017). Antibody blood-brain barrier efflux is modulated by glycan modification. Biochim. Biophys. Acta 1861, 2228-2239. doi: 10.1016/j.bbagen.2017.06.008

Freeman, G. B., Brown, T. P., Wallace, K., and Bales, K. R. (2012). Chronic administration of an aglycosylated murine antibody of ponezumab does not worsen microhemorrhages in aged Tg2576 mice. Curr. Alzheimer Res. 9, 1059-1068. doi: 10.2174/156720512803569064

Freir, D. B., Fedriani, R., Scully, D., Smith, I. M., Selkoe, D. J., Walsh, D. M., et al. (2011). A $\beta$ oligomers inhibit synapse remodelling necessary for memory consolidation. Neurobiol. Aging 32, 2211-2218. doi: 10.1016/j.neurobiolaging.2010.01.001

Frost, J. L., Liu, B., Rahfeld, J. U., Kleinschmidt, M., O’nuallain, B., Le, K. X., et al. (2015). An anti-pyroglutamate- $3 \mathrm{~A} \beta$ vaccine reduces plaques and improves cognition in APPswe/PS1DeltaE9 mice. Neurobiol. Aging 36, 3187-3199. doi: 10.1016/j.neurobiolaging.2015.08.021

Fuller, J. P., Stavenhagen, J. B., Christensen, S., Kartberg, F., Glennie, M. J., and Teeling, J. L. (2015). Comparing the efficacy and neuroinflammatory potential of three anti-a $\beta$ antibodies. Acta Neuropathol. 130, 699-711. doi: 10.1007/s00401-015-1484-2

Harold, D., Abraham, R., Hollingworth, P., Sims, R., Gerrish, A., Hamshere, M. L., et al. (2009). Genome-wide association study identifies variants at CLU and PICALM associated with Alzheimer's disease. Nat. Genet. 41, 1088-1093. doi: 10.1038/ng.440

He, W., and Barrow, C. J. (1999). The A $\beta$ 3-pyroglutamyl and 11-pyroglutamyl peptides found in senile plaque have greater $\beta$-sheet forming and aggregation propensities in vitro than full-length A $\beta$. Biochemistry 38, 10871-10877. doi: 10.1021/bi990563r

Hefti, F., Goure, W. F., Jerecic, J., Iverson, K. S., Walicke, P. A., and Krafft, G. A. (2013). The case for soluble $A \beta$ oligomers as a drug target in Alzheimer's disease. Trends Pharmacol. Sci. 34, 261-266. doi: 10.1016/j.tips.2013.03.002

Hollingworth, P., Harold, D., Sims, R., Gerrish, A., Lambert, J. C., Carrasquillo, M. M., et al. (2011). Common variants at ABCA7, MS4A6A/MS4A4E, EPHA1, CD33 and CD2AP are associated with Alzheimer's disease. Nat. Genet. 43, 429-435. doi: 10.1038/ng.803

Holmes, C., Boche, D., Wilkinson, D., Yadegarfar, G., Hopkins, V., Bayer, A., et al. (2008). Long-term effects of A $\beta 42$ immunisation in Alzheimer's disease: followup of a randomised, placebo-controlled phase I trial. Lancet 372, 216-223. doi: 10.1016/S0140-6736(08)61075-2

Hu, N. W., Klyubin, I., Anwyl, R., and Rowan, M. J. (2009). GluN2B subunit-containing NMDA receptor antagonists prevent $\mathrm{A} \beta$-mediated synaptic plasticity disruption in vivo. Proc. Natl. Acad. Sci. U.S.A. 106, 20504-20509. doi: 10.1073/pnas.0908083106

Ide, M., Harris, M., Stevens, A., Sussams, R., Hopkins, V., Culliford, D., et al. (2016). Periodontitis and cognitive decline in Alzheimer's disease. PLoS ONE 11:e0151081. doi: 10.1371/journal.pone.0151081

Imbimbo, B. P., Ottonello, S., Frisardi, V., Solfrizzi, V., Greco, A., Seripa, D., et al. (2012). Solanezumab for the treatment of mild-to-moderate Alzheimer's disease. Expert Rev. Clin. Immunol. 8, 135-149. doi: 10.1586/eci.11.93

Jawhar, S., Wirths, O., and Bayer, T. A. (2011). Pyroglutamate amyloid- $\beta$ (A $\beta$ ): a hatchet man in Alzheimer disease. J. Biol. Chem. 286, 38825-38832. doi: 10.1074/jbc.R111.288308

Kalback, W., Watson, M. D., Kokjohn, T. A., Kuo, Y. M., Weiss, N., Luehrs, D. C., et al. (2002). APP transgenic mice Tg2576 accumulate A $\beta$ peptides that are distinct from the chemically modified and insoluble peptides deposited in Alzheimer's disease senile plaques. Biochemistry 41, 922-928. doi: 10.1021/bi015685+

Kamat, P. K., Vacek, J. C., Kalani, A., and Tyagi, N. (2015). Homocysteine induced cerebrovascular dysfunction: a link to Alzheimer's disease etiology. Open Neurol. J. 9, 9-14. doi: 10.2174/1874205X01509010009

Kastanenka, K. V., Bussiere, T., Shakerdge, N., Qian, F., Weinreb, P. H., Rhodes, K., et al. (2016). Immunotherapy with aducanumab restores calcium homeostasis in Tg2576 Mice. J. Neurosci. 36, 12549-12558. doi: 10.1523/JNEUROSCI.2080-16.2016

Kessels, H. W., Nabavi, S., and Malinow, R. (2013). Metabotropic NMDA receptor function is required for $\beta$-amyloid-induced synaptic depression. Proc. Natl. Acad. Sci. U.S.A. 110, 4033-4038. doi: 10.1073/pnas.1219605110 
Kummer, M. P., and Heneka, M. T. (2014). Truncated and modified amyloid- $\beta$ species. Alzheimers Res. Ther. 6:28. doi: 10.1186/alzrt258

Lannfelt, L., Moller, C., Basun, H., Osswald, G., Sehlin, D., Satlin, A., et al. (2014). Perspectives on future Alzheimer therapies: amyloid- $\beta$ protofibrils - a new target for immunotherapy with BAN2401 in Alzheimer's disease. Alzheimers Res. Ther. 6:16. doi: 10.1186/alzrt246

Lee, S. H., Le Pichon, C. E., Adolfsson, O., Gafner, V., Pihlgren, M., Lin, H., et al. (2016). Antibody-mediated targeting of tau in vivo does not require effector function and microglial engagement. Cell Rep. 16, 1690-1700. doi: 10.1016/j.celrep.2016.06.099

Lei, M., Xu, H., Li, Z., Wang, Z., O'malley, T. T., Zhang, D., et al. (2016). Soluble A $\beta$ oligomers impair hippocampal LTP by disrupting glutamatergic/GABAergic balance. Neurobiol. Dis. 85, 111-121. doi: 10.1016/j.nbd.2015.10.019

Lewis, H., Beher, D., Cookson, N., Oakley, A., Piggott, M., Morris, C. M., et al. (2006). Quantification of Alzheimer pathology in ageing and dementia: age-related accumulation of amyloid- $\beta$ (42) peptide in vascular dementia. Neuropathol. Appl. Neurobiol. 32, 103-118. doi: $10.1111 / j .1365-2990.2006 .00696 . x$

Leyhe, T., Andreasen, N., Simeoni, M., Reich, A., Von Arnim, C. A., Tong, X., et al. (2014). Modulation of $\beta$-amyloid by a single dose of GSK933776 in patients with mild Alzheimer's disease: a phase I study. Alzheimers Res. Ther. 6:19. doi: 10.1186/alzrt249

Li, T., Dilillo, D. J., Bournazos, S., Giddens, J. P., Ravetch, J. V., and Wang, L. X. (2017). Modulating IgG effector function by Fc glycan engineering. Proc. Natl. Acad. Sci. U.S.A. 114, 3485-3490. doi: 10.1073/pnas.1702173114

Lista, S., Toschi, N., Baldacci, F., Zetterberg, H., Blennow, K., Kilimann, I., et al. (2017). Diagnostic accuracy of CSF neurofilament light chain protein in the biomarker-guided classification system for Alzheimer's disease. Neurochem. Int. 108, 355-360. doi: 10.1016/j.neuint.2017.05.010

Logovinsky, V., Satlin, A., Lai, R., Swanson, C., Kaplow, J., Osswald, G., et al. (2016). Safety and tolerability of BAN2401-a clinical study in Alzheimer's disease with a protofibril selective $\mathrm{A} \beta$ antibody. Alzheimers Res. Ther. 8:14. doi: 10.1186/s13195-016-0181-2

Lunnon, K., Teeling, J. L., Tutt, A. L., Cragg, M. S., Glennie, M. J., and Perry, V. H. (2011). Systemic inflammation modulates Fc receptor expression on microglia during chronic neurodegeneration. J. Immunol. 186, 7215-7224. doi: 10.4049/jimmunol.0903833

Maarouf, C. L., Daugs, I. D., Kokjohn, T. A., Kalback, W. M., Patton, R. L., Luehrs, D. C., et al. (2010). The biochemical aftermath of anti-amyloid immunotherapy. Mol. Neurodegener. 5:39. doi: 10.1186/1750-1326-5-39

Masters, C. L., Simms, G., Weinman, N. A., Multhaup, G., McDonald, B. L., and Beyreuther, K. (1985). Amyloid plaque core protein in Alzheimer disease and Down syndrome. Proc. Natl. Acad. Sci. U.S.A. 82, 4245-4249. doi: $10.1073 /$ pnas. 82.12 .4245

Miles, L. A., Crespi, G. A., Doughty, L., and Parker, M. W. (2013). Bapineuzumab captures the $\mathrm{N}$-terminus of the Alzheimer's disease amyloid- $\beta$ peptide in a helical conformation. Sci. Rep. 3:1302. doi: 10.1038/srep01302

Miller, D. L., Papayannopoulos, I. A., Styles, J., Bobin, S. A., Lin, Y. Y., Biemann, K., et al. (1993). Peptide compositions of the cerebrovascular and senile plaque core amyloid deposits of Alzheimer's disease. Arch. Biochem. Biophys. 301, 41-52. doi: 10.1006/abbi.1993.1112

Moro, M. L., Giaccone, G., Lombardi, R., Indaco, A., Uggetti, A., Morbin, M., et al. (2012). APP mutations in the A $\beta$ coding region are associated with abundant cerebral deposition of A 338 . Acta Neuropathol. 124, 809-821. doi: 10.1007/s00401-012-1061-x

Morris, A. W., Carare, R. O., Schreiber, S., and Hawkes, C. A. (2014). The cerebrovascular basement membrane: role in the clearance of $\beta$ amyloid and cerebral amyloid angiopathy. Front. Aging Neurosci. 6:251. doi: $10.3389 /$ fnagi.2014.00251

Morris, J. C., Storandt, M., McKeel, D. W. Jr., Rubin, E. H., Price, J. L., Grant, E. A., et al. (1996). Cerebral amyloid deposition and diffuse plaques in "normal" aging: evidence for presymptomatic and very mild Alzheimer's disease. Neurology 46, 707-719. doi: 10.1212/WNL.46.3.707

Nicoll, J. A., Wilkinson, D., Holmes, C., Steart, P., Markham, H., and Weller, R. O. (2003). Neuropathology of human Alzheimer disease after immunization with amyloid- $\beta$ peptide: a case report. Nat. Med. 9, 448-452. doi: 10.1038/nm840

Niewoehner, J., Bohrmann, B., Collin, L., Urich, E., Sade, H., Maier, P., et al. (2014). Increased brain penetration and potency of a therapeutic antibody using a monovalent molecular shuttle. Neuron 81, 49-60. doi: 10.1016/j.neuron.2013.10.061

Nilsberth, C., Westlind-Danielsson, A., Eckman, C. B., Condron, M. M., Axelman, K., Forsell, C., et al. (2001). The 'Arctic' APP mutation (E693G) causes Alzheimer's disease by enhanced $\mathrm{A} \beta$ protofibril formation. Nat. Neurosci. 4 , 887-893. doi: 10.1038/nn0901-887

Novakovic, D., Feligioni, M., Scaccianoce, S., Caruso, A., Piccinin, S., Schepisi, C., et al. (2013). Profile of gantenerumab and its potential in the treatment of Alzheimer's disease. Drug Des. Dev. Ther. 7, 1359-1364. doi: 10.2147/DDDT.S53401

Ostrowitzki, S., Deptula, D., Thurfjell, L., Barkhof, F., Bohrmann, B., Brooks, D. J., et al. (2012). Mechanism of amyloid removal in patients with Alzheimer disease treated with gantenerumab. Arch. Neurol. 69, 198-207. doi: 10.1001/archneurol.2011.1538

Pardridge, W. M. (2016). Re-engineering therapeutic antibodies for Alzheimer's disease as blood-brain barrier penetrating bi-specific antibodies. Expert Opin. Biol. Ther. 16, 1455-1468. doi: 10.1080/14712598.2016.1230195

Pedersen, J. T., and Sigurdsson, E. M. (2015). Tau immunotherapy for Alzheimer's disease. Trends Mol. Med. 21, 394-402. doi: 10.1016/j.molmed.2015. 03.003

Perez-Garmendia, R., and Gevorkian, G. (2013). Pyroglutamate-modified amyloid $\beta$ peptides: emerging targets for Alzheimer s disease immunotherapy. Curr. Neuropharmacol. 11, 491-498. doi: 10.2174/1570159X11311050004

Perez-Garmendia, R., Hernandez-Zimbron, L. F., Morales, M. A., Luna-Muñoz, J., Mena, R., Nava-Catorce, M., et al. (2014). Identification of N-terminally truncated pyroglutamate amyloid- $\beta$ in cholesterol-enriched diet-fed rabbit and AD brain. J. Alzheimers Dis. 39, 441-455. doi: 10.3233/JAD-130590

Perl, D. P. (2010). Neuropathology of Alzheimer's disease. Mt. Sinai J. Med. 77, 32-42. doi: $10.1002 / \mathrm{msj} .20157$

Piazza, F., and Winblad, B. (2016). Amyloid-Related Imaging Abnormalities (ARIA) in immunotherapy trials for Alzheimer's disease: need for prognostic biomarkers? J. Alzheimers Dis. 52, 417-420. doi: 10.3233/JAD-160122

Piccini, A., Russo, C., Gliozzi, A., Relini, A., Vitali, A., Borghi, R., et al. (2005). $\beta$ amyloid is different in normal aging and in Alzheimer disease. J. Biol. Chem. 280, 34186-34192. doi: 10.1074/jbc.M501694200

Portelius, E., Bogdanovic, N., Gustavsson, M. K., Volkmann, I., Brinkmalm, G., Zetterberg, H., et al. (2010). Mass spectrometric characterization of brain amyloid $\beta$ isoform signatures in familial and sporadic Alzheimer's disease. Acta Neuropathol. 120, 185-193. doi: 10.1007/s00401-010-0690-1

Reinert, J., Richard, B. C., Klafki, H. W., Friedrich, B., Bayer, T. A., Wiltfang, J., et al. (2016). Deposition of C-terminally truncated $A \beta$ species $A \beta 37$ and $A \beta 39$ in Alzheimer's disease and transgenic mouse models. Acta Neuropathol. Commun. 4:24. doi: 10.1186/s40478-016-0294-7

Rinne, J. O., Brooks, D. J., Rossor, M. N., Fox, N. C., Bullock, R., Klunk, W. E., et al. (2010). 11C-PiB PET assessment of change in fibrillar amyloid- $\beta$ load in patients with Alzheimer's disease treated with bapineuzumab: a phase 2, double-blind, placebo-controlled, ascending-dose study. Lancet Neurol. 9, 363-372. doi: 10.1016/S1474-4422(10)70043-0

Saito, T., Suemoto, T., Brouwers, N., Sleegers, K., Funamoto, S., Mihira, N., et al. (2011). Potent amyloidogenicity and pathogenicity of A $\beta 43$. Nat. Neurosci. 14, 1023-1032. doi: $10.1038 / \mathrm{nn} .2858$

Salloway, S., Sperling, R., Fox, N. C., Blennow, K., Klunk, W., Raskind, M., et al. (2014). Two phase 3 trials of bapineuzumab in mild-to-moderate Alzheimer's disease. N. Engl. J. Med. 370, 322-333. doi: 10.1056/NEJMoa1304839

Salloway, S., Sperling, R., Gilman, S., Fox, N. C., Blennow, K., Raskind, M., et al. (2009). A phase 2 multiple ascending dose trial of bapineuzumab in mild to moderate Alzheimer disease. Neurology 73, 2061-2070. doi: 10.1212/WNL.0b013e3181c67808

Sattlecker, M., Khondoker, M., Proitsi, P., Williams, S., Soininen, H., Kłoszewska, I., et al. (2016). Longitudinal protein changes in blood plasma associated with the rate of cognitive decline in Alzheimer's disease. J. Alzheimers Dis. 49, 1105-1114. doi: 10.3233/JAD-140669

Scheltens, P. (2015). "Biomarker Data from SCarlet RoAd - a Global Phase 3 Study of Gantenerumab in Patients with Prodromal AD," in The Alzheimer's Association International Conference (AAIC). Available online at: https://www. alz.org/aaic/abstracts/abstr-archives.aspI

Schieb, H., Kratzin, H., Jahn, O., Mobius, W., Rabe, S., Staufenbiel, M., et al. (2011). $\beta$-amyloid peptide variants in brains and cerebrospinal fluid from 
amyloid precursor protein (APP) transgenic mice: comparison with human Alzheimer amyloid. J. Biol. Chem. 286, 33747-33758. doi: 10.1074/jbc.M111. 246561

Selkoe, D. J., and Hardy, J. (2016). The amyloid hypothesis of Alzheimer's disease at 25 years. EMBO Mol. Med. 8, 595-608. doi: 10.15252/emmm.2016 06210

Sevigny, J., Chiao, P., Bussière, T., Weinreb, P. H., Williams, L., Maier, M., et al. (2016). The antibody aducanumab reduces $A \beta$ plaques in Alzheimer's disease. Nature 537, 50-56. doi: 10.1038/nature 19323

Soejitno, A., Tjan, A., and Purwata, T. E. (2015). Alzheimer's disease: lessons learned from amyloidocentric clinical trials. CNS Drugs 29, 487-502. doi: 10.1007/s40263-015-0257-8

Sperling, R. A., Jack, C. R. Jr., Black, S. E., Frosch, M. P., Greenberg, S. M., Hyman, B. T., et al. (2011). Amyloid-related imaging abnormalities in amyloid-modifying therapeutic trials: recommendations from the Alzheimer's association research roundtable workgroup. Alzheimers Dement. 7, 367-385. doi: 10.1016/j.jalz.2011.05.2351

Strittmatter, W. J., Weisgraber, K. H., Huang, D. Y., Dong, L. M., Salvesen, G. S., Pericak-Vance, M., et al. (1993). Binding of human apolipoprotein E to synthetic amyloid $\beta$ peptide: isoform-specific effects and implications for late-onset Alzheimer disease. Proc. Natl. Acad. Sci. U.S.A. 90, 8098-8102. doi: 10.1073/pnas.90.17.8098

Sudduth, T. L., Powell, D. K., Smith, C. D., Greenstein, A., and Wilcock, D. M. (2013). Induction of hyperhomocysteinemia models vascular dementia by induction of cerebral microhemorrhages and neuroinflammation. J. Cereb. Blood Flow Metab. 33, 708-715. doi: 10.1038/jcbfm.2013.1

Sumbria, R. K., Hui, E. K., Lu, J. Z., Boado, R. J., and Pardridge, W. M. (2013). Disaggregation of amyloid plaque in brain of Alzheimer's disease transgenic mice with daily subcutaneous administration of a tetravalent bispecific antibody that targets the transferrin receptor and the A $\beta$ amyloid peptide. Mol. Pharm. 10, 3507-3513. doi: 10.1021/mp40 $0348 \mathrm{n}$

Teeling, J. L., and Perry, V. H. (2009). Systemic infection and inflammation in acute CNS injury and chronic neurodegeneration: underlying mechanisms. Neuroscience 158, 1062-1073. doi: 10.1016/j.neuroscience.2008. 07.031

Tucsek, Z., Toth, P., Tarantini, S., Sosnowska, D., Gautam, T., Warrington, J. P., et al. (2014). Aging exacerbates obesity-induced cerebromicrovascular rarefaction, neurovascular uncoupling, and cognitive decline in mice. J. Gerontol. A Biol. Sci. Med. Sci. 69, 1339-1352. doi: 10.1093/gerona/g lu080

Vandenberghe, R., Rinne, J. O., Boada, M., Katayama, S., Scheltens, P., Vellas, B., et al. (2016). Bapineuzumab for mild to moderate Alzheimer's disease in two global, randomized, phase 3 trials. Alzheimers. Res. Ther. 8:18. doi: 10.1186/s13195-016-0189-7

Viticchi, G., Falsetti, L., Buratti, L., Boria, C., Luzzi, S., Bartolini, M., et al. (2015). Framingham risk score can predict cognitive decline progression in Alzheimer's disease. Neurobiol. Aging 36, 2940-2945. doi: 10.1016/j.neurobiolaging.2015.07.023
Viticchi, G., Falsetti, L., Buratti, L., Sajeva, G., Luzzi, S., Bartolini, M., et al. (2017). Framingham risk score and the risk of progression from mild cognitive impairment to dementia. J. Alzheimers Dis. 59, 67-75. doi: 10.3233/JAD-170160

Weekman, E. M., Sudduth, T. L., Caverly, C. N., Kopper, T. J., Phillips, O. W., Powell, D. K., et al. (2016). Reduced efficacy of anti-a $\beta$ immunotherapy in a mouse model of amyloid deposition and vascular cognitive impairment comorbidity. J. Neurosci. 36, 9896-9907. doi: 10.1523/JNEUROSCI.1762-16.2016

Weitz, T. M., and Town, T. (2016). Amyloid cascade into clarity. Immunity 45, 717-718. doi: 10.1016/j.immuni.2016.10.006

Whalley, L. J., Dick, F. D., and McNeill, G. (2006). A life-course approach to the aetiology of late-onset dementias. Lancet Neurol. 5, 87-96. doi: 10.1016/S1474-4422(05)70286-6

Wilcock, D. M., Alamed, J., Gottschall, P. E., Grimm, J., Rosenthal, A., Pons, J., et al. (2006). Deglycosylated anti-amyloid- $\beta$ antibodies eliminate cognitive deficits and reduce parenchymal amyloid with minimal vascular consequences in aged amyloid precursor protein transgenic mice. J. Neurosci. 26, 5340-5346. doi: 10.1523/JNEUROSCI.0695-06.2006

Wilcock, D. M., and Colton, C. A. (2009). Immunotherapy, vascular pathology, and microhemorrhages in transgenic mice. CNS Neurol. Disord. Drug Targets 8, 50-64. doi: 10.2174/187152709787601858

Wirths, O., Walter, S., Kraus, I., Klafki, H. W., Stazi, M., Oberstein, T. J., et al. (2017). N-truncated $A \beta 4$-x peptides in sporadic Alzheimer's disease cases and transgenic Alzheimer mouse models. Alzheimers Res. Ther. 9:80. doi: 10.1186/s13195-017-0309-Z

Yu, Y. J., Atwal, J. K., Zhang, Y., Tong, R. K., Wildsmith, K. R., Tan, C., et al. (2014). Therapeutic bispecific antibodies cross the blood-brain barrier in nonhuman primates. Sci. Transl. Med. 6:261 ra154. doi: 10.1126/scitranslmed.3009835

Zekry, D., Hauw, J. J., and Gold, G. (2002). Mixed dementia: epidemiology, diagnosis, and treatment. J. Am. Geriatr. Soc. 50, 1431-1438. doi: 10.1046/j.1532-5415.2002.50367.x

Zuchero, Y. J., Chen, X., Bien-Ly, N., Bumbaca, D., Tong, R. K., Gao, X., et al. (2016). Discovery of novel blood-brain barrier targets to enhance brain uptake of therapeutic antibodies. Neuron 89, 70-82. doi: 10.1016/j.neuron.2015.11.024

Conflict of Interest Statement: AA is a full time employee of $\mathrm{H}$ lundbeck A/S. JT and $\mathrm{RE}$ have received funding from $\mathrm{H}$ Lundbeck $\mathrm{A} / \mathrm{S}$.

The other author declares that the research was conducted in the absence of any commercial or financial relationships that could be construed as a potential conflict of interest.

Copyright (c) 2018 Sumner, Edwards, Asuni and Teeling. This is an open-access article distributed under the terms of the Creative Commons Attribution License (CC $B Y)$. The use, distribution or reproduction in other forums is permitted, provided the original author(s) and the copyright owner are credited and that the original publication in this journal is cited, in accordance with accepted academic practice. No use, distribution or reproduction is permitted which does not comply with these terms. 